\title{
Agricultural and food systems in the Mekong region: Drivers of transformation and pathways of change [version 1; peer
}

\section{review: 2 approved]}

\author{
Richard M. Friend1, Samarthia Thankappan1, Bob Doherty (1D2, Nay Aung3, \\ Astrud L. Beringer ${ }^{4}$, Choeun Kimseng ${ }^{5}$, Robert Cole 6,7 , Yanyong Inmuong ${ }^{8}$, \\ Sofie Mortensen ${ }^{9}$, Win Win Nyunt ${ }^{3}$, Jouni Paavola (D10, Buapun Promphakping ${ }^{11}$, \\ Albert Salamanca9 ${ }^{9}$ Kim Soben ${ }^{12}$, Saw Win ${ }^{13}$, Soe Win (iD)14, Nou Yang ${ }^{15}$ \\ ${ }^{1}$ Human Geography and Environment, University of York, York, North Yorkshire, YO105GD, United Kingdom \\ ${ }^{2}$ The York Management School, University of York, York, North Yorkshire, YO105GD, United Kingdom \\ 3 University of Mandalay, Mandalay, Myanmar \\ ${ }^{4}$ Rural Poor Institute for Land and Human Rights Services, Manila, Philippines \\ ${ }^{5}$ Department of Development Studies, Royal University of Phnom Penh (RUPP), Phnom Penh, Cambodia \\ ${ }^{6}$ Department of Geography, National University of Singapore, 21 Lower Kent Ridge Road, Singapore \\ ${ }^{7}$ Centre for Social Development Studies, Chulalongkorn University, Bangkok, Thailand \\ ${ }^{8}$ Faculy of Environment and Resource Studies, Mahasarakham University, Khamriang Sub-District, Thailand \\ ${ }^{9}$ SEI-Asia, Stockholm Environment Institute, Bangkok, Thailand \\ ${ }^{10}$ Faculty of Environment, University of Leeds, Leeds, West Yorkshire, United Kingdom \\ ${ }^{11}$ Department of Social Development, Khon Kaen University, Khon Kaen, Thailand \\ ${ }^{12}$ Royal University of Agriculture, Phnom Penh, Cambodia \\ ${ }^{13}$ Renewable Energy Association, Climate Resilience, Yangon, Myanmar \\ ${ }^{14}$ Geography, Maubin University, Maubin, Myanmar \\ ${ }^{15}$ Northern Agriculture and Forestry College, (NAFC), Luang Prabang, Lao Peoples Democratic Republic
}

V1 First published: 15 May 2019, 1:12

https://doi.org/10.12688/emeraldopenres.13104.1

Latest published: 15 May 2019, 1:12

https://doi.org/10.12688/emeraldopenres.13104.1

\section{Abstract}

Agricultural and food systems in the Mekong Region are undergoing transformations because of increasing engagement in international trade, alongside economic growth, dietary change and urbanisation. Food systems approaches are often used to understand these kinds of transformation processes, with particular strengths in linking social, economic and environmental dimensions of food at multiple scales. We argue that while the food systems approach strives to provide a comprehensive understanding of food production, consumption and environmental drivers, it is less well equipped to shed light on the role of actors, knowledge and power in transformation processes and on the divergent impacts and outcomes of these processes for different actors. We suggest that an approach that uses food systems as heuristics but complements it with attention to actors, knowledge and power improves our understanding of transformations such as those

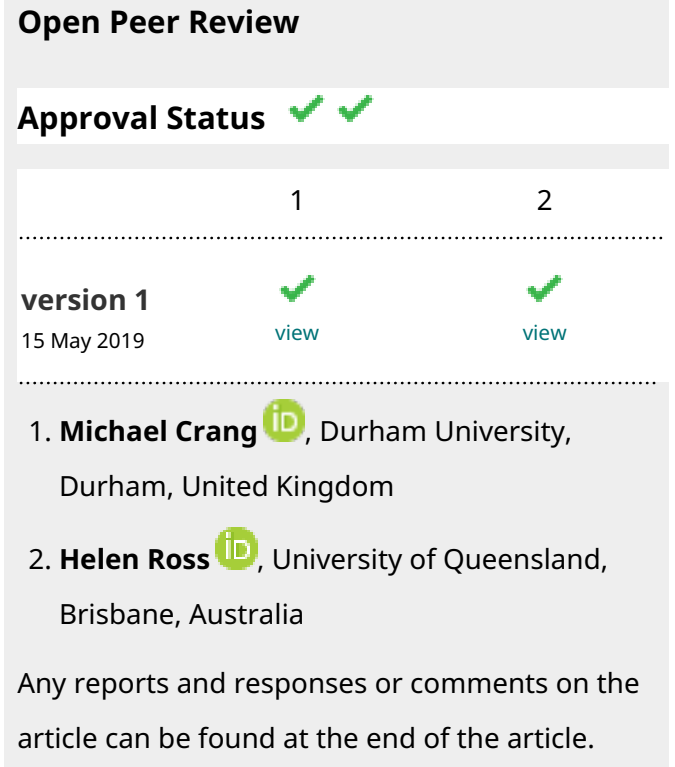


underway in the Mekong Region. The key transformations in the region include the emergence of regional food markets and vertically integrated supply chains that control increasing share of the market, increase in contract farming particularly in the peripheries of the region, replacement of crops cultivated for human consumption with corn grown for animal feed. These transformations are increasingly marginalising small-scale farmers, while at the same time, many other farmers increasingly pursue non-agricultural livelihoods. Food consumption is also changing, with integrated supply chains controlling substantial part of the mass market. Our analysis highlights that theoretical innovations grounded in political economy, agrarian change, development studies and rural livelihoods can help to increase theoretical depth of inquiries to accommodate the increasingly global dimensions of food. As a result, we map out a future research agenda to unpack the dynamic food system interactions and to unveil the social, economic and environmental impacts of these rapid transformations. We identify policy and managerial implications coupled with sustainable pathways for change.

\section{Keywords}

Food Systems, Agrarian Change, Food Transitions, Commodification, Value Chains, Environmental Change, Rural Livelihoods, Contract Farming and Dietary Transition

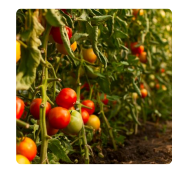

This article is included in the Sustainable Food

Systems gateway.

Corresponding author: Bob Doherty (bob.doherty@york.ac.uk)

Author roles: Friend RM: Conceptualization; Thankappan S: Conceptualization; Doherty B: Conceptualization; Aung N: Conceptualization; Beringer AL: Conceptualization; Kimseng C: Conceptualization; Cole R: Conceptualization; Inmuong Y Conceptualization; Mortensen S: Conceptualization; Nyunt WW: Conceptualization; Paavola J: Conceptualization; Promphakping B: Conceptualization; Salamanca A: Conceptualization; Soben K: Conceptualization; Win S: Conceptualization; Win S: Conceptualization; Yang N: Conceptualization

Competing interests: No competing interests were disclosed.

Grant information: This research is part of the N8 Agrifood programme funded by the Higher Education Funding Council for England. The funders had no role in study design, data collection and analysis, decision to publish, or preparation of the manuscript.

Copyright: (c) 2019 Friend RM et al. This is an open access article distributed under the terms of the Creative Commons Attribution License, which permits unrestricted use, distribution, and reproduction in any medium, provided the original work is properly cited.

How to cite this article: Friend RM, Thankappan S, Doherty B et al. Agricultural and food systems in the Mekong region: Drivers of transformation and pathways of change [version 1; peer review: 2 approved] Emerald Open Research 2019, 1:12 https://doi.org/10.12688/emeraldopenres.13104.1

First published: 15 May 2019, 1:12 https://doi.org/10.12688/emeraldopenres.13104.1 


\section{Introduction}

This paper focuses on the Mekong Region a part of the world that is going through dramatic food system change that is unfolding at multiple scales, from the scale of the farming household to a process of political and economic regionalisation and globalisation, within a context of global environmental change (Reardon et al., 2019). While each of these scales of change has been targeted by specific theoretical approaches, the challenge that we see is to be able to address the inter-linkages and dependencies between and across scales (Cash et al., 2006). This requires a combination of disciplinary approaches that draw on complex social-ecological-technological systems, political economy and political ecology, as well as actor-oriented sociology/anthropology. In doing so, we are taken back to fundamental challenges of social science; of how to reconcile the way in which systems shape human action, and the ways in which such systems are shaped by social, historical and political processes, raising the additional question of how such systems might be reshaped, or transformed, for different ends into the future.

Our regional focus on the Mekong has wider global significance, setting out a research agenda to unpack the dynamic, multi-faceted food system interactions, and the social, economic and environmental implications of these rapid transformations. Such a research agenda has practical implications for policy and practice, providing an analytical framework for identifying pathways for change that are sustainable and equitable. Specifically, this paper brings together theory and literature that is grounded in concepts of food systems, agrarian change, political economy and sustainable livelihoods. Food systems is increasingly influential when looking at the global challenges around production, trade, distribution and consumption of food, bringing together social, political, economic and environmental dimensions. It is a conceptual approach that highlights inter-linkages providing a framework for analysing relationships, dynamics and implications of change (Ingram, 2011). Yet this macro-scale focus of food systems struggles to i) consider the political and governance dimensions to how such systems are created, and for whose interests and benefit, or ii) to accommodate the diversity of human action, especially in areas of the world going through dramatic change. In contrast, while rural livelihoods focus on the household and recognises the broader influence of multiple transforming structures and processes (markets, policy, norms and institutions), it has struggled either conceptually or methodologically to accommodate the increasingly complex multi-scale interlinkages and interdependencies, and their influence on rural change. Similarly, the literature on agrarian change while addressing the influence of globalisation and capital penetration has tended to focus on the scale of small-scale production of specific crops (Hart et al., 2016).

This paper argues the need to take both the macro (regional and global) scale of food systems with the scale of household livelihoods, and the interfaces and relations between them as entry points for analysis. Food systems are fundamentally social, political and economic creations, driven by specific interests and agendas. Increased agricultural production in the Mekong region is directly related to the expansion of the agricultural frontier, and market penetration of what have historically been marginal lands, resources and rural societies. Our primary concern is in understanding the implications of these trajectories of change, and how these interactions can be shaped in ways that deliver social and economic benefits to small-scale farmers, while also meeting broader social and environmental objectives.

We argue that, while the food systems approach strives to provide a comprehensive understanding of food production and consumption, it is less well equipped to shed light on the role of actors, knowledge and power in transformation processes and on the divergent impacts and outcomes of these processes for different actors. We suggest that an approach that uses food systems as heuristics but complements it with attention to actors, knowledge, governance and power helps better understand transformations such as those underway in the Mekong Region. This paper is anchored in the food system, food transition and food regime literature, which are reviewed in section 2. We then look in section 3 at the food system transitions affecting the Mekong Region to highlight the rapid nature of these changes along with their impacts. The paper concludes in Section 4 with conclusions, implications for practice/policy and a future research agenda.

\section{Food systems}

It has become something of a truism in the burgeoning field of food studies to describe food as constituting a 'system' (Ericksen, 2008; Kneen, 1993; Sobal et al., 1998; Tendall et al., 2015). This is seen as a way to improve food system outcomes and sustainability, in order to deal with competing priorities and address the complex relationships that exist between components of the food system (Ericksen, 2008). Yet this concept is invoked far more often than it is defined satisfactorily (Doherty et al., 2019). Although food studies lay claims to interdisciplinary research - as the 'food systems' concept implies - in practice traditional disciplinary divisions of work have created and maintained a range of methods and approaches to the study of food. This does not mean that researchers have deliberately ignored or dismissed food research stemming from other disciplines. Rather, it is suggestive of the deep-rooted obstacles - epistemological, ontological and methodological - standing in the way of genuine interdisciplinary research without prior commitment to a shared conceptual and analytical framework. The first step to overcoming these obstacles is therefore to commit to constructing such a framework by engaging with and extending the extant food systems literature especially those accounts that have sought to delineate an explicit and interdisciplinary food systems research programme. While the literature is now growing, there are still relatively few contributions that succeed in delineating an explicit conceptualisation of the food system. Examples of the latter include: Ericksen (2008); Gregory et al. (2005); Ingram (2011); Rotz \& Fraser (2015); Sobal et al. (1998); Tendall et al. (2015); and Horton et al. (2017). These contributions share an understanding that food needs to be studied holistically in order to capture the multiple activities, interactions and outcomes associated with its production, exchange, consumption and governance. Tendall et al. (2015) argue that food system research thus far has overemphasised biophysical shocks and has neglected political economy and governance. Reardon et al. (2019) also proposes 
that food system studies to date have prioritised on farm food systems and calls for more work on the post farm gate activities where $40-70 \%$ of the food value is added. These tasks, however, are easier said than done given the inherent complexity of the food system and the various ways it intersects with other social, health and environmental systems.

With the aspiration of reaching a more comprehensive understanding of the defining characteristics and boundaries of the food system, we recognise that an holistic framework is required. A common feature of the available literature is the distinction made between processes (or activities), drivers and outcomes. The food system is not just characterised by separate activities producing collective outcomes; it is the dynamic interaction between units (or subsystems) that outlines the systemic properties at play. Food system activities and outcomes eventually result in processes that feed back to environmental and socioeconomic drivers (Ericksen, 2008), which may lead to unintended consequences (Ingram et al., 2011). The food system is thus defined by its dynamic properties, which involve information flows between the system and its components and between the system and the external environment beyond the system boundary. These complex interactions and their implications need to be considered for in the design and implementation of effective policy and management interventions. Such interventions, thus, cannot be treated as isolated changes in one part of the food system (Pinstrup-Andersen \& Watson, 2011). These current contributions above are useful; however, they fail to consider political economy, governance and agency and there is a need to build a more nuanced approach that considers these political aspects. Tendall et al. (2015) calls for more participatory approaches to food system studies are needed with more empirical data (quantitative and qualitative). Therefore, this paper now investigates in depth some of the key food system transitions in the Mekong region.

\section{Agrarian and food transitions in the Mekong}

Researchers (for example, Bello et al., 1998; Bullard et al., 1998; and Davis, 2004) have interpreted agrarian change in a multitude of ways, where the market integration and economic restructuring in the Asian context has been interpreted as disruptive, and sometimes against development. Yet another school of researchers (for example, Cramb et al., 2015; De Koninck \& Ahmat, 2012; Molle \& Srijantr, 1999; Wittayapak, 2012) claim positive development processes are operating in rural areas, through the introduction of new crops and market opportunities increasing farm incomes and better paid non-farm employment opportunities. Recent literature identifies significant interacting agrarian and food transitions within Southeast Asia (Reardon \& Timmer, 2012; Reardon et al., 2019; Rigg et al., 2016; Thapa et al., 2010; Wahlqvist et al., 2012) including commodification of food and agriculture, environmental change, sociodemographic transition (for example, rural-urban migration), and dietary transition. These transitions and some of their key features are synthesised by the authors in Table 1 below.

Rigg et al. (2012) provide an interesting argument: that the nature and direction of agrarian transformation has often been either misconstrued or unanticipated, due to development practitioners and researchers viewing rural change from different vantage points, i.e. focus on rural spaces (the countryside), farming and the agricultural sector, rural livelihoods, and rural settlements (villages). Following on from the above argument, considering the farming and agricultural sector as an entry point, Rigg et al. (2012) claim that farming remains a key activity in some areas and a central thread in sustaining livelihoods. This entry point requires tracing the patterns of land use and ownership, and transformations in agricultural systems from biochemical technologies to labour relations, mechanization, contract farming, and linkages with global agro-food networks.

Table 1. Agrarian \& food transitions.

\begin{tabular}{|c|c|}
\hline Food system transitions & Features \\
\hline $\begin{array}{l}\text { Commodification of food and } \\
\text { intensification of agriculture }\end{array}$ & $\begin{array}{l}\text { Policy liberalization and privatisation has resulted in: land use change (e.g. monocultures), } \\
\text { cash cropping in the uplands (e.g. maize production), rising use and cost of inputs, land } \\
\text { grabbing, contract farming, increasing farm debt, food insecurities, increasing influence of } \\
\text { large agribusiness and vertical integration (e.g. Charoen Pokphand Foods), intensification } \\
\text { leading to overuse of chemical inputs, globalisation and regionalization of food trade. Also } \\
\text { increase in medium-small enterprises in the food system }\end{array}$ \\
\hline Environmental change & $\begin{array}{l}\text { Changing weather patterns, extreme flooding and drought, acidification of soils, rapid } \\
\text { deforestation and associated burning (haze) plus loss of biodiversity, water salinity, fluctuating } \\
\text { water levels and declining fisheries plus increasing chemical burden. Plus increasing food } \\
\text { insecurity }\end{array}$ \\
\hline Rural livelihoods & $\begin{array}{l}\text { Changing socio-demographics of rural livelihoods leading to growing insecurities, rural -urban } \\
\text { migration, feminization of agriculture, rising middle classes }\end{array}$ \\
\hline Dietary transition & $\begin{array}{l}\text { Increasing consumption of meat and processed foods, increasing incidence of non- } \\
\text { communicable diseases. Higher proportion of non-staples particularly in urban areas } \\
\text { (Bennett's Law) }\end{array}$ \\
\hline $\begin{array}{l}\text { Structural changes in value } \\
\text { chains }\end{array}$ & $\begin{array}{l}\text { Contract farming, elongation of supply chains, increased competition, declining farmers share } \\
\text { of total value, increasing role of technologies, processing and transport plus increasing public } \\
\text { and private standards, land grabbing }\end{array}$ \\
\hline Infrastructure changes & Dams and hydroelectric power along key waterways, major road construction \\
\hline
\end{tabular}


These transitions are leading to an emerging regional food system that is more interlinked and interdependent, but that is also creating new fault lines of risk and potential vulnerabilities. It is a food system that is overwhelmingly a product of policies, and strategies that are market based, and that are underpinned by a discourse of progress and positive change. Despite these social, economic, and environmental transitions, small-scale farmers have persisted in the Mekong region (Rigg et al., 2016). Engel's law proposes that, as nations move through economic transformation, people move out of agriculture and average farm size increases. However, in Southeast Asia, particularly Thailand, farmers are now more numerous and farm size is becoming smaller. This is set against a backdrop of rapid economic development (uneven), therefore challenging theory and historical assumptions. Therefore, according to the World Bank, particularly in the lower income countries of Cambodia, Lao and Myanmar, there is considerable remaining scope to pursue agriculturebased growth (Rigg et al., 2016). Rural populations remain high, for example $79 \%$ in Cambodia, $41 \%$ in Thailand with small-scale farmers accounting for $84 \%$ percent of landholdings (Rigg et al., 2016).

Yet these statistics mask a complexity across the small-scale farmers and rural society. Classification of occupation in rural society often fails to capture the complexity and diversity of household livelihood strategies. It is worth noting though, that for many small-scale farmers in the Mekong, their livelihoods are not met only from farming. While small-scale farmers persist in numbers, their ability to shape decisions about how the farm has long been undermined by unequal power relations with increasingly influential national and regional food system actors (Rigg et al., 2016; Rigg \& Nattapoolwat, 2001). To tackle the aforementioned transitions equitably and sustainably, Wahlqvist et al. (2012) call for a wider notion of food security to broaden its concept to include issues such as health, impacts of migration and more resilient environmental approach and improved governance. However, they fail to call for an approach to tackle the complexity, or the power relations that both shape and are shaped by emerging food systems. In order to address suitably the points raised above, the concept of food regimes also needs to be understood and unpacked.

Friedmann \& McMichael (1989) claim that the concept of 'foodregime' has been associated with specific periods of hegemony and dominant transitions in capitalist history, where food was incorporated into consumption relations as industrial food system categorised diets with value-added foods, fast foods etc. (Friedmann, 1992). Araghi (2003) sees food regime as a political regime of global value relations, where food is intrinsic to capital's global value relations. Under the first food regime, which was characterised by the British domination, firms and states reduced the cost of labour through mass production of staple food and key food commodities. The second food regime according to Davis (2004) and Shove \& Walker (2010) stabilised American farmers by reorganising agriculture and the surpluses of which provisioned food manufacturers across the world with subsidised food aid that reduced labour costs (Patel, 2007). Further, as manufacturing moved offshore, agribusinesses developed around commodity specialisations that established the industrialisation of food. The food regime thus so far, according to McMichael (2009), represented politicised value relations through colonial geo-politics and served to reduce wages in regions of industrialised capital accumulation. The current food regime as shaped by the previous regimes, however, has its own distinctive relationships, wherein markets are the principal organising forces.

The colossal global movement of food is forcing the increased movement of people by undermining peasant agriculture. We are currently witnessing, how neoliberal policies have encouraged agribusiness consolidation and dismantling national marketing boards, elimination of small farmer subsidies and rural credit. This liberalisation of trade and investment relations has accelerated de-peasantisation (McMichael, 2005). This article will now look in more depth at specific transitions affecting smallscale farmers particularly, rural livelihoods (socio-demographic change), intensification and commodification, environmental change plus structural change dietary transitions.

\subsection{Rural livelihoods in transition}

Impressions of the demise of small-scale farmers in the Mekong region have been exaggerated, and their persistence in various forms has contributed to challenges of understanding the dynamics of agrarian and rural change. However, situating small-scale farmers in a shifting landscape of agrarian, political, economic and environmental change continues to present conceptual and methodological challenges.

Such conceptual complexity is mirrored in the ambiguous place of small-scale farmers in regional and national policy. While small-scale farmers have long been considered among the poorest people in each of the countries, the focus of policy has been ambiguous. The nature of smallholding and associated notions of inefficiency and ineffectiveness have been identified as the cause of their poverty (Deininger \& Beyerlee, 2012). Policy directed at small-scale farming has tended towards poverty alleviation; that is to say, to avoid further impoverishment of small-scale farmers, while encouraging transitioning out of agriculture and off the land as the ultimate strategy for poverty reduction. It has been assumed by policy makers in the Mekong region that economic evolution would inevitably lead to their demise, as farmers moved into other sectors that would be more productive for national economic growth, while the agriculture sector itself would shift in scale and intensity with greater mechanisation and processing. From such a perspective, the persistence of small-scale agriculture represents a barrier to economic efficiencies and ultimately to national development. Alternatively, agricultural development is considered particularly effective, when it increases returns to small-scale farmers and generates employment for the poor (FAO, 2012; WFP, 2012 and IFAD, 2012).

Current evidence suggests that small-scale farming in the Mekong continues at a significant scale. It is estimated there are 400-500 million small-scale farms worldwide, and of these, nearly 90\% are in Asia (Conway, 2011). It is likely that 2 billion 
people or nearly a third of the world's population are reliant on smallholdings for their livelihood. Despite clear trends towards urbanisation and the growth of industrial and manufacturing sectors, agriculture and the rural population remain enormously significant in each of the Mekong countries. Rigg et al. (2018) identified five key features, which explain this persistence of the small-scale farmer:

- The agro-ecology of wet rice is difficult to upscale, particularly if you bear in mind an ageing farming population. Where is the motivation?

- Compression of the agrarian transition with ageing farming population de-agrarianised without depeasantisation.

- The conceptualisation of the farm household shows the farm as a site of production, consumption and redistribution of food.

- The precarity of non-farm work, which can be high risk, short term no safety night.

- $\quad$ The cultural stickiness of land; "if there is no land where can I stand".

There is an important caveat to this type of analysis. Official statistics have consistently underestimated and misrepresented residence in the urban or rural (Coxhead, 2015). This is partly attributable to terminologies and official definitions of what constitutes both urban and rural. This is largely defined by density of population. Such definitions are further complicated by how migrant or mobile populations are officially registered, and the difficulty, or reluctance of migrants to re-register after moving to the city. Counting a population that is increasingly on the move is thus increasingly challenging. This apparent neglect in policy is evidenced at both regional and national levels. As one of the key drivers of regionalisation, ASEAN's policy focus has been on economic integration, yet despite the continued significance of agriculture in national economies, and the large numbers of people engaged in agricultural production, there is no reference to small-scale farmers in the ASEAN Economic Community Blueprint 2025 (2015).

As the largest economy in the region, the experience of Thailand is illustrative of national policy priorities. Since the mid-1980s, Thailand's national development strategy has been clearly shaped by a commitment to export-led growth that has positioned agriculture in terms of agro-industry, focusing on export of specific agricultural products. Alongside this policy orientation, there is a history of the role of small-scale farmers being explicitly rejected by both politicians and policy makers. For instance, amid the pressure from rice farmers in central plain, demanding the government to deal with the plummeting price of rice paddy in the early 1990s, the then-Prime Minister, Chuan Leekpai, stated to the media that farmers or agriculture will eventually disappear from Thai economy. This general policy perspective has endured, illustrated by the current $12^{\text {th }}$ National Economic and Social Development Plan, which makes only one reference to small-scale farmers. In contrast, the 2030 Agenda for Sustainable Development places emphasis on small-scale producers, identifying who these people are and their important role.
Much of the focus on agriculture in the Mekong region has been on rice. Rice production has had a privileged position in agricultural research (Cramb et al., 2015) as well as in cultural imaginations and in the ways that rural people refer to themselves. This representation often overlooks the wide range of agricultural activities that are undertaken within the household, and that vary according to gender and age, as well as seasonality. Even for households who do not enjoy rice security for the full twelve months of the year, or who only spend a relatively small proportion of their time engaged in rice production, may refer to themselves as rice farmers in some way, yet may also spend a greater proportion of their labour in a range of different agricultural activities, including fishing and harvesting aquatic animals, raising livestock, collecting non-timber forest products, and in cultivating a wide range of crops.

This tendency to focus on rice farming as the defining characteristic of agricultural livelihoods has been identified as a factor in the relative neglect of fisheries, despite their significance in rural diets in many parts of the region. The apparent neglect of inland fisheries in national statistics has long been identified as both a knowledge gap, and an impediment to effective policy prioritisation and action (FAO, 2018). Of the major inland fisheries in the region, the Mekong basin has been most researched, and is now widely acknowledged as being one of the most productive inland fisheries in the world. The Mekong River alone produces 2.6 million fish/year, which represents seven times the inland fisheries production in North America (FAO, 2018). However, the full scale of production and its livelihood importance remains difficult to gauge. What is known about fisheries is based on detailed but still limited studies rather than reliable statistics, with consumption studies suggest per capita figures of around $24-36 \mathrm{~kg} /$ person/year. The problem remains that the majority of what is produced is consumed, and what is measured is only what is landed, a tiny proportion at best. The situation is repeated in other major river basins of the region - the Red, Chao Phraya, Irrawaddy, and Salween.

Efforts to unpack the concept of the farmer in the region led to adoption of rural livelihoods as being characterised by diverse portfolios, and as being dynamic and adaptive. Attention to the relationship between livelihoods and ecological circumstances has also generated the application of terms such as 'wetland livelihoods' (Friend, 2007) or 'forest livelihoods' that themselves highlight a diversity of and inter-relationships between agricultural practice and natural resource use. This diversity in livelihood strategies becomes all the more apparent when comparing across the countries of the region, and across agro-ecological zones. Increasingly off-farm employment constitutes the most significant contribution to rural household income, often generated from distant locations; a phenomenon that Winkels (2011) refers to as 'stretched livelihoods'. Parsons et al. (2014) demonstrate how urban workers in Cambodia, from women in garment factories, construction workers to motorcycle taxi drivers, continue to provide remittances to their rural households, returning to their villages for critical seasons in agricultural production cycle. It is through this rural livelihood perspective that the connectivity between urban and rural space and modes of production can be seen. This degree of what Rigg \& Salamanca (2015) refer to as 'pluriactivity' is a feature of rural livelihoods in 
Northeast Thailand, increasingly encompassing employment of migrant labour by those who might have been classified previously as small-scale farmers, but who now are termed agricultural entrepreneurs. Given the transboundary nature of migration, these connectivity's increasingly stretch across national boundaries.

Within this diversity of rural livelihoods, identifying the smallscale farmer is additionally problematic. The debate in the academic literature raises questions of the criteria by which the small-scale should be defined - whether according to amount of land occupied (as suggested by the term 'small-scale'); the nature of land access (whether owned or rented); motivations and degree of engagement in market relations (whether for inputs or sale), the use of labour outside the core family unit, and the type of agricultural activity and the degree of engagement in 'traditional' agricultural practices (see Rigg et al., 2016). Similarly, McElwee (2006) distinguishes between three categories of smallholder; 'traditional producers' who maintain established practices of production, 'entrepreneurial smallholders' who are engaged in use of improved agricultural technology and off-farm labour markets, and 'sub-contractor smallholders' as those who employ labour or rent out their land. The classification of the 'small-scale' is similarly problematic in the realm of fisheries, with debate concentrating on the degree to which such status is determined by the fishing gear that are used, volume of catch, use of hired labour, and the relative degree of subsistence to market engagement. Even those who depend on fisheries as part of diversified rural livelihoods may refer to themselves as farmers (Friend, 1997). Yet in parts of Vietnam's Mekong delta, the relative importance of aquatic animals in household activity, and nutrition presents a case for representing such people as fishers who farm, rather than farmers who fish (Béné \& Friend, 2011).

One of the most significant agricultural transitions is away from harvesting natural resources; a trend that is seen in pressures on small-scale capture fisheries (both inland and coastal), away from harvesting non-timber forest products (NTFPs) and hunting, plus the constraints on upland households to engage in shifting agriculture. While narratives of inevitable decline of such natural resources persist, this trend can be seen as symptomatic of the closing of natural resource frontiers and commodification of the resources and the land and waters on which they depend. Yet similar challenges can be seen facing people's access to and control over forest, fisheries and water resources, shifting patterns of ownership and resource extraction, and exclusion and displacement.

\subsection{Commodification of food and intensification of agriculture}

The agricultural transformation of Asia needs to be placed in a broad historical context. Expansion of production has historically been most closely associated with the expansion of the area of land under cultivation, with production moving into ever more marginal lands, as global market opportunities created potential for accumulation from poor quality soils and limited irrigation. For example, since the mid-nineteenth century Thailand (Siam) has been linked to global markets. From 1855 to 1974 Siam's rice production grew 28 times while population only doubled, from 6 to 12 million (Delang, 2002). Yet while overall production increased dramatically, production per hectare had been in steep decline by the 1970s. First, the share of agricultural output in GDP has been declining more rapidly than that of employment. At present, while agriculture remains the largest sector in terms of employment in Asia, it is no longer the largest sector in terms of GDP in any Asian country. Second, agricultural productivity in Asia has grown faster than in other developing regions. Third, technological change in agriculture since the 1960s has led to significant improvements in the yield of traditional crops. Fifth, the composition of agricultural output of developing Asia has shifted from traditional to high-value crops (Briones \& Felipe, 2013).

Over the past few years, primarily in response to various government policies and the expansion of regional, national and international markets, the Mekong region has witnessed transitions in farmers' strategies. However, the region has never before seen large-scale changes as are occurring currently. Financial gains have come with costs. While incomes have increased, farmers have fewer livelihood options, fewer opportunities to collect non-timber forest products (NTFPs), and, less food security (Fu et al., 2010). With the reduction of diverse swidden agriculture systems, the traditional exchange of forest products between indigenous groups has been disrupted. With less overall natural forest cover and increasing distances from villages to remaining patches of forest, people derive less income from the collection of NTFPs (Fu et al., 2009). The traditional ecological knowledge base and aesthetic and cultural practices have been eroded, with farmers more dependent on crops that are priced on the world market which local people have limited knowledge of (Xu et al., 2005). In terms of the overall agrarian transformations, the impacts on rural people across the developing world is a contested area (Bernstein, 2002; Rigg, 2006). In the Mekong region, while the long-term impact of intensive agriculture on small-scale farmers is not yet clearly documented; one thing is certain, traditional livelihood systems are in the midst of dramatic changes.

Agricultural intensification in Thailand has been associated with irrigation or water provision, market availability, credit access, the application of high yield varieties and modern agricultural inputs (Purotaganon \& Schmidt-Vogt, 2014). In Thailand, there is 57.29 million rai of land grown with paddy, which are concentrated in the Central Plains and the Northeast. The irrigated paddy lands are scattered across 18 provinces in the Central, North and the Northeast of Thailand with a total area of 1.934 million rai (ca. 320000 hectares). The total rice production of the main crops varies between 25 and 30 million tons, with the second crop constituting 3.7 million tons of paddy. The second crop production has declined recently due to limited supply of irrigation water in the face of sustained droughts. From this amount of production, about 18 million tons of paddy serve domestic consumption and the rests are for exports (approximately 10 million tons of rice). Thai rice exports represent approximately 25 percent of the world market (Seck et al., 2012). Water feeding irrigation systems are from 482 large and medium sized reservoirs, with a total storage capacity of 75,154 million cubic meters (Walker, 2003). Water from the 
government irrigation system is currently provided to farmers without fees. It should be noted here that irrigation for small-scale farmers has evolved in different forms, supported by both government and business. These include traditional irrigation (gravity), underground water pumping, and small household reservoirs. Meanwhile, large-scale irrigation requires the construction of large reservoirs, which is challenging due to the availability of land for building reservoirs, negative environmental impacts, and high costs. In recent decades, government and businesses have started to promote the idea of water diversion across country boundaries and watersheds to feed the existing dams. Due to rapid urbanisation, there is growing tension surrounding water allocation between agriculture and modern economic sectors. In addition, rice cultivation practices have changed considerably. These changes are partly in response to labour shortages in agriculture; subsequent agricultural mechanization is also coupled with using high-yield varieties, inorganic fertilizers, and pesticides.

Given the fluctuation of the world market price of rice, and the large number of farmers, rice cultivation has long been enmeshed in national politics. At present, there are 3,741,346 rice farm households registered with the Thai government system, with the total land area of 48,495,315 rai. Improvements in living standards, together with competing labour demand in the agricultural sector have increased the cost per unit of production (Chainuvati \& Athipanan, 2011). Such pressures have been exacerbated by declines in market prices leading farmers to pressure the government to provide support. Such support has been built around subsidies, of which the key policy intervention has been the rice mortgage scheme. The Yingluck Shinawatra Thai government scaled up the scheme by significantly increasing state subsidies for rice (Permani \& Vanzetti, 2016). Due to alleged corruption, the military junta halted the policy. Demands for state support, such as this, are not limited to the needs of rice farmers. The widespread state promotion of rubber production across the country has put large numbers of farmers at risk to the impacts of declining global prices, with similar demands from farmers, especially in the South of the country, for state support.

The dependence on and vulnerability to the fluctuation of the world market has contributed to a pattern of boom and bust across different agricultural crops. For example, Thailand is among top three of the largest world cassava producers and has been the largest world exporters together with Brazil and Nigeria (Waddington et al., 2010). In 2016, the official statistics indicated that cassava was grown on about 8.4 million rai of land with a total volume of production at around 31.19 million tons. Over 73 percent of cassava were exported, mainly in the form of flour and pellet, and with the remainder for domestic consumption. Compared with rice growers, however, cassava growers are less able to influence the political dynamics. During the past 20 years, cassava growers have declined due to falling prices and a number of cassava growers in the Northeast have turned to growing sugarcane. There is also a policy measure to promote cassava for biofuel production but how this affects cassava prices in the domestic market is yet unclear.

\subsection{Structural changes in value chains}

Contract farming has emerged as a new mechanism by which producers and markets are linked, and production relations commercialised. Contract farming has become a key mechanism for promoting rural economic development that is favoured by the state, alongside considerable private sector support. The Cambodian government passed the Sub-decree on Contract Farming in 2011 with the stated aims of improving market access and productivity (Sreymom \& Pirom, 2015). Eaton \& Shepherd (2001) point to the range of contractual arrangements in operation: centralized and multipartite, which is based on documented contracts, or informal and intermediary mechanisms, which are based on informal, verbal contracts. While more formalized contracts appear to deliver clearer benefits to farmers, their own preference is for informality and flexibility. Contract farming in Thailand has a long history. However, the term 'contract farming' only appeared in formal state policy for the first time in the $6^{\text {th }}$ National Economic and Social Development Plan (1987-1991). Under this Plan, the government augmented the so-called Four Sector Cooperation Plan, which includes agrobusinesses, farmers, financial institutions (the Bank for Agriculture and Agricultural Cooperative - BAAC) and the state agencies. This policy framework provided the platform for early contract farming under the arrangement of the state. Although the Office of Agriculture noted some problems at the end of the $6^{\text {th }}$ National Development Plan, it was recommended that contract farming be further promoted. There was no explicit mention of contract farming after the $8^{\text {th }}$ National Development Plan, but the government agencies continue to implement this mechanism. The Thai private sector has been encouraged to extend contract farming schemes to neighbouring countries under the sub-regional economic cooperation agreement called "Ayerawady-Chao Phraya-Mekong Economic Cooperation Strategy" (ACMECS) (Sriboonchitta et al., 2008).

Contract farming is presented as a means to solve the problem of access to agricultural inputs of smallholders (Reardon et al., 2019). This includes technical knowledge, which had been previously provided by state agricultural extension services. Across the region, state extension services have proved to be weak, facing particular challenges in meeting the needs of smaller farmers. This is often attributed to limited institutional capacity and budgets. For instance, in Myanmar, the Ministry of Agriculture has imposed strict limits on travel budgets since 2006 so that farmers may never have met an extension agent, and where they are left to their own networks, and private sector for access to inputs and technical advice (Anderson Irrigation, 2012; MSU/MDRI/CESD, 2013).

Contract farming is argued to be a mitigation to deal with the price fluctuation of agricultural commodities. The government, as well as international development agencies such as World Bank and Asian Development Bank, see contract farming as an effective tool to raise the productivity of agriculture of developing countries, where small-scale farmers are the majority. However, there are criticisms on the negative impacts of contract farming. These criticisms include concerns about the fairness of economic distribution between small-scale farmers and businesses and its impacts on health and 
environment. Contract farming is the favoured mechanism through which international capital is invested in agricultural production, and in some cases, in land ownership (and land grabbing). The way in which emerging actors and alliances across market and state interests shape food systems is a critical dimension of the Mekong story. Credit mechanisms have also encouraged investment in larger agri-business rather than smallholders. The practical difficulties of administering loans to small-scale farmers led to reduced investment by the Bank of Agriculture and Cooperatives (Phongpaichit \& Baker, 1998). The cooperation between small-scale farmers and large agribusiness to intensify agriculture and enhance small-scale farmer's livelihoods could be a distinctive path of transformation. However, the evidence on the impacts of contract farming contested. Contract farming for cabbage, maize, and sugarcane in Laos have led to improvements in income (Manorom et al., 2011). However, it is also important to consider the time-frame of such improvements, and the potential impacts of environmental degradation that are associated with some contract farming methods and to price fluctuations in global markets. There are cases where small-scale farmer rubber plantations have lifted people out of poverty in Southern Thailand (Fox \& Castella, 2013). However, with the recent collapse of the rubber price, which has declined $40 \%$ since 2016, this may no longer be the case.

One of the most influential agri-businesses in the world, Chareon Pokaphand Group (CPG), has grown from Thailand's engagement in contract farming. CP was founded in 1921 in Thailand. It began as a small firm selling seed and its current largest business is Chareon Pokphand Food (CPF). At present, there are 127 companies operating under CPF. There are 96 companies operating in Thailand, 17 companies overseas and 14 companies involved in other non-agriculture businesses. CPF income in 2012 was 209,313 million baht. Of this, 154,149 million baht was earned in Thailand alone. In 2010, there were 5000 direct contracts under the CPF which include chicken meat, swine, layer farm and duck meat (Laurujisawat, 2012). CPF is vertically integrated with contract farming arrangements for crop production including animal feed for their own livestock production, plus processing and manufacturing of foods for sale through a network of CPF-owned retail outlets.

Contract farming is also widespread in the production of nonfood crops. The longest existing contract farming arrangements is in sugarcane and sugar production. During 2005 to 2010, there was an increase in price of agricultural commodities, driving the expansion of areas planted to sugarcane in Thailand. At present, there are 51 sugar mills, with the aggregate capacity of 105.96 million tons of sugarcane, spread mostly in the Central Plain and the Northeast of Thailand. In fact, Thailand is now the second largest global exporter of sugarcane after Brazil. The leading companies are Mitrphol and Thai Rung Reung, with market shares of 21 percent and 15 percent, respectively. The official statistics report that in 2013-2014 there were 11.03 million rai (representing about 11.56 of the total agricultural land) grown with sugarcane, producing a total of 94.05 million tons. There were 309,821 growers involved, who are mostly smallscale farmers. However, recently Thailand has decided to cut its exports of raw sugar by at least 500,000 tons this year, as a swelling global surplus and falling prices make it less worthwhile to export. The 500,000 tons is to be sold to local ethanol producers. In addition to plummeting prices, there are concerns regarding over use of chemicals such as the herbicide, Paraquat. The scale of operations of companies such as CPF have enormous significance for what occurs at the scale of rural households involved in contract farming production, and the refashioning of ecological landscapes where such production occurs.

The situation for non-food production in the Mekong region is even more dramatic. For example, Laos' non-food production index tripled in 2014. Increasing trends are also shown in Myanmar and Vietnam. Non-food production includes commodities such as tea, coffee, and animal feed, and due to their low nutritional values are not consumed. Drawing on data from Land Matrix (2016), the increasing trend is in part explained by large-scale land acquisitions predominantly for non-food production. Asia is the second largest receiver of large-scale land investments after Africa, and it is estimated that $50 \%$ of the Asian investments occurs within Southeast Asia. Indonesia is the largest receiver in the world, based on size of concluded deals (Nolte et al., 2017). Cambodia and Laos are also amongst the top 20 receivers globally, but data is largely missing for Myanmar, despite reports of high incidence rate (Nolte et al., 2017). Importantly, these numbers do not include land investments, or land grabs, initiated by states or domestic companies into crop plantations suggesting that numbers are even higher. The influx of foreign investments in land is not the only factor leading to land grabs.

The common explanation of the global land grab is the convergence of food, energy and economic crises in 2007-2008; however, this obscures other processes taking place in the Mekong region (Hirsch \& Scurrah 2015b; Schoenberger et al., 2017). Land grabbing occurred in the early 2000s in most of the region and is not only driven by foreign private companies but also domestic and state (companies) (Schoenberger et al., 2017). Additionally, investments are not only seen within crop and tree plantations, but also in hydropower, urban infrastructure development, state-territorialisation, and special economic zones to mention some. However, whilst some of these processes are not new, they are accelerating and supported by state policies, particularly in Cambodia, Laos (Schoenberger et al., 2017) and Myanmar (Franco et al., 2015). Further, 'green grabbing', i.e. conservation and carbon storage has brought in new actors such as NGOs, excluding or even controlling farmers' access to forest resources (Fairhead et al., 2012). Other trends include more everyday processes of accumulation including small-scale land grabs, e.g. urban elites acquiring land in rural areas (Tubtim, 2012) or rental markets between locals and migrants which have cumulative impacts, in addition to distress sales (Hirsch et al., 2015a).

The role of Thailand and Vietnam as purveyors of land grabs through cross-border contracts in other countries in the region should not obscure that land grabbing also takes place within states (Schoenberger et al., 2017). In Vietnam, the state acquires large amounts of land for industrial, infrastructural and urbanization purposes (Dao, 2015). In Thailand, although to a lesser extent, forest lands are acquired for conservation and mining activities (Schoenberger et al., 2017). Whilst these 
create tensions and conflicts in Vietnam, policies in Thailand have been more in favour of protecting smallholders (Hirsch et al., 2015b; Schoenberger et al., 2017). Thailand and Vietnam's experience have been described as accumulation without dispossession as smallholders are largely embedded in markets and in contract farming (Diepart, 2016). In Vietnam, for example, $40 \%$ of exported rice is produced under contract farming schemes. Contract farming, therefore, is seen as an untapped resource in the poorer Mekong countries.

To counterbalance this rapid intensification of agriculture, there has been the growth of alternative approaches such as organic farming, integrated farming, natural farming, agro-forestry farming, and sufficiency farming. These approaches are based on a number of common principles:

- Based on holistic production management system,

- $\quad$ Promote and enhance agro-ecosystem health, biodiversity, biological cycles etc.

- $\quad$ Reduce the use of off-farm chemical inputs,

- Accomplished by using cultural, biological, and mechanical methods as opposed to synthetic materials,

The growing popularity of organic farming is driven by several factors (Sangkumchaliang \& Huang, 2012). First is the growing concern of health and wellbeing, especially among urban populations. Consuming natural and safe foods is seen as important for preventative health care. The second trend is the response to the overuse of chemicals within the agricultural sector; particularly in the production of cash crops, this drove the demand for more sustainable approaches, particularly from the NGO movement. In 1989, the Alternative Agricultural Network (AAN) was formed and the activities of the network were mainly focused on creating a system for transferring sustainable farming knowledge and experience to grassroots NGOs and farmer leaders.

\subsection{Environmental change}

Food systems provides a comprehensive analytical framework to address the environmental dimensions of food across the cycle of production to consumption, from the ways in which production leads to reshaping of ecological landscapes and use of natural resources but also in ways that are less immediately obvious. How the cycle of growth, seeding and decomposition of crops no longer occurs at the local scale as food crops are transported across the globe (Goodman \& Redclift, 2002), to the feedback loops between consumption of meat leads to production patterns of animal feed that have local environmental impacts. Moreover, the grounding in complex social-ecological-systems highlights environmental inter-linkages and feedback loops whereby actions at various points across food systems have implications at other locations and for other actors.

Environmental change has been a prominent feature in the transformations of small-scale agriculture. As can be gleaned from the agrarian change literature, the expansion of the volume of agricultural production was clearly linked to the expansion of the area of land under cultivation, and encroachment on forest resources. The experience of the Mekong region is consistent with wider regional trends. From 2000 to 2010, Asia, including Cambodia, Myanmar and Thailand, among others, experienced a significant net agricultural gain of 13,484 hectares and net forest loss of 10,562 hectares (FAO, 2016). Large-scale agriculture is a deforestation driver. In the Mekong Sub-region, Cambodia's forest cover is still declining, while Myanmar's forest showed an alarming decline during 2010 and 2015 (Yasmi et al., 2017). Lao PDR and Thailand gained forest areas due to an increase of naturally regenerated forests or secondary forests and in the case of Lao PDR, due to reclassification. However, when seen over a longer time frame, the changes in land use are more stark. For example, from 1990-2015 Cambodia records a loss of $58 \%$ of its primary forest cover, while Lao PDR records a loss of 25\% (Yasmi et al., 2017). Thailand's forested area had already declined to less than $40 \%$ by 1990 . Such assessments are complicated by the ways in which forests are classified, with a general trend across the countries to incorporate secondary and plantation forest in these calculations.

Agriculture in the Mekong region is a sector that is widely identified as being especially vulnerable to the impacts of climate change (ADB, 2017a; Johnston et al., 2009). Climate variability and extreme events are expected to decrease agricultural yields, cause fresh water scarcity, and loss of biodiversity and ecosystem services (ADB, 2014). A study conducted on rice yield in Cambodia found that climate change could result in a reduction of 5 percent by 2020, 25 percent by 2050 and 45 percent by 2080 (ADB, 2014). In Thailand, the 2011 floods resulted in high economic damage and agricultural losses (ADB, 2017a). In 2010, 2015 and 2016, Thailand experienced its worst droughts. In 2014 and 2015, the annual accumulated rainfall in Thailand fell below the 30-year average (1981-2010) for two consecutive years, affecting dry season rice crops on over 3.4 million rai or 544,000 hectares in 2016 (SCB, 2016). The impact of climate change also contributes to increased scarcity of resources, which amplify conflicts over access to resources that are already degraded and under pressure (Friend \& Thinphanga, 2018). Underpinning vulnerability to climate change are structural vulnerabilities and governance failures, with small-scale rural livelihoods already undermined by competition over productive resources, and limited access to agricultural inputs, knowledge and markets (UNDP, 2011).

Intensification of agricultural production has also raised concerns regarding soil fertility across the Mekong region, with shorter fallow cycles and removal of crop residue reducing organic matter and nitrogen and widespread use of inorganic fertilisers, except for Myanmar. The combination of changes in land use, loss of forest, and climate related shifts in precipitation may also exacerbate patterns of soil erosion (FAO, 2011; FAO, 2005; FAO, 1993). Many of these changes are already evident with $53 \%$ of land in Cambodia identified as having low fertility (Blair \& Blair, 2014)

\subsection{Infrastructure change and dietary transitions}

These rapid transformations have put significant pressure on the natural resource base and rural communities caught up in 
the shift from small-scale and subsistence agriculture to commodification, driven by large-scale agribusiness targeting export markets (ADB, 2017). Dramatic changes in agricultural, commercial and consumption practices have threatened the livelihoods of small-scale farmers and led to the degradation of land, water, plant and animal resources upon which regional food security depends (Thapa et al., 2010). The expansion of hydropower and road infrastructure, land-intensive commercial farming and extractive industries have driven dramatic rates of deforestation, the expropriation of public land and the refashioning of river basins and floodplains (Darby et al., 2016). The Mekong river system, which supports the world's largest inland fishery and constitutes the main source of animal protein in the region, is fundamental to food security, especially in the Lower Mekong Basin, whose population is expected to increase to 90 million by 2025 (Lu \& Siew, 2006). The Mekong and other river basins are under threat from changed watershed management and damming, creating protein deficits at a time of population growth and dietary transitions that are more proteinintensive (Biba, 2012). Protein deficiency is strongly correlated with the prevalence of macro- and micronutrient deficiency, especially in rural areas, which together with increasing levels of overweight/obesity among burgeoning urban populations amounts to a 'triple burden' of malnutrition (Gomez et al., 2013).

Changing value chains combined with technological advances in refrigeration and transport innovations (e.g. cargo transport) have made meat and processed food products more accessible to both urban and rural communities (Reardon et al., 2019). This along with increasing urbanisation in the Mekong region has resulted in a "double burden" of malnutrition; levels of malnutrition and stunting are highly prevalent in rural areas, alongside concurrent increases in levels of overweight and obesity in urban areas (Haddad et al., 2015). In rural areas, protein-energy malnutrition and micronutrient deficiencies remain public health concerns, particularly in less affluent countries in the Mekong region and in the poorest population groups. Lao PDR and Cambodia are predominantly experiencing undernutrition with limited data for Myanmar available (Haddad et al., 2015). Unhealthy dietary practices in urban areas, increased importation of cheap food and proliferation of fast food outlets have increased the consumption of westernised diets and the expense of traditional diets, with concomitant impacts on health and the sustainability of production. As a result, the Mekong region shows one of the highest global rates of increase in overweight individuals during the past 30 years. Childhood obesity is of increasing concern in Thailand. Large-scale surveys conducted showed that overweight and obesity prevalence is approaching $20 \%$ amongst both preschool children, and schoolaged children (Winichagoon, 2013). Of concern, adiposity in school-aged children was inversely related to iron deficiency and reduced response to iron fortification. Maternal nutrition and diet related chronic disease Type 2 diabetes. There is increasing evidence that the presence of gestational diabetes mellitus (GDM) and possibly, the intensity and duration of lactation are risk factors for developing type 2 diabetes among women in later adulthood. It has also been observed that the prevalence of obesity among adult women was higher than among men $(43 \%$ and $30 \%$, respectively), using body mass index.
Already established in this paper is the rapid economic development in the Mekong. The pressure for this growth to be transferred into citizen wellbeing is significant. However, this goal is threatened by a number of reasons including rising inequality, the double burden of malnutrition (Bowlen, 2012). Urban populations purchase the majority of the food they consume, supermarkets, convenience stores and fast food chains have been expanding rapidly in the Mekong (Reardon et al., 2019). There has been a move away from non-staples and also a surge in demand for processed meat products which has been translated into the rise in demand for maize as feed grain. This has resulted in deforestation and burning and its associated haze pollution.

\section{Discussion and conclusions}

In this paper, we have synthesised from the literature the key market based agrarian and food transitions taking place in the Mekong Region. By taking a food systems approach, we have been able to identify some of the key drivers of these transitions at different scales, key stresses and shocks, and some of the outcomes for the food system (Ingram, 2011). However, the paper clearly shows that food systems alone does not capture the complexity of the changes particularly with regard to the experiences of small-scale farmers. Also, the agrarian change literature by Cramb et al. (2015) fails to uncover the complexity of the pressures on small-scale farmers. The paper raises questions regarding the need to unpack small-scale farmer pluriactivity and the precarity of rural livelihoods faced with the volatility of global markets and environmental change. Particularly, the dynamics of non-agricultural work on rural communities. In addition, there is limited work in the Mekong on the governance of value chains and the power relationships in these contract farming supply chains coupled with the governance of natural resources. It is clear there is a need for work focused on the food regime of private standards and the invisibility of commodity impact. This supports the call by Reardon et al. (2019) for the need for more work on the food system activities beyond the farm gate. Moreover, the paper clearly demonstrates the importance of land and marine fisheries in the Mekong and the need for urgent work to assess the neglect of this vital protein source and other dietary transitions including increasing challenges brought about by the 'triple burden' of malnutrition.

We understand food as a complex socio-ecological system and as the basis for an integrated and coherent approach to the analysis of both the system itself and options open to different stakeholders. Our framework recognises the motives of different food system actors in the Mekong region, and the range of policy, market, social, technological and biophysical environments that influence decision making. It thus allows food chain activities to be linked to their social, economic and environmental contexts. Moreover, as actors in each section of the food chain affect each other's behaviour, two-way linkages are taken into account. This recognition of food system interactions opens up space to explore adaptation options to improve outcomes across the full set of food system activities. Capturing these interactions provides a framework for systematic assessment of food system status and for the analysis of synergies and tradeoffs of possible interventions to be balanced across a range of developmental needs, priorities and goals. 
However, taking the current depiction of a food systems or agrarian change approaches alone does not deal adequately with the inter-linkages and dependencies between and across scales particularly with power and governance. This requires a combination of disciplinary approaches that draw on complex social-ecological-technological systems, political economy and political ecology, as well as actor-oriented sociology/anthropology. In doing so, we are taken back to fundamental challenges of social science: of how to reconcile the way in which systems shape human action, and the ways in which such systems are shaped by social, historical and political processes, raising the additional question of how such systems might be reshaped, or transformed, for different ends into the future.

\section{Policy and managerial implications}

The paper has identified the need to use food systems as heuristics but complementing with attention to actors, knowledge and power will help to better understand transformations such as those underway in the Mekong Region. This will allow policy makers to assess both trade-offs and unintended consequences. It is also clear there needs to be a much more inclusive and participatory approach to working with small-scale farmers to incorporate them into policy making. This is particularly important in relation to the UN Sustainable Development Goals. Both national and regional policy making along with the design of private standards will need to consider rural livelihoods coupled with sustainable management of landscapes. Furthermore, policy making with regard to hydropower and road infrastructure and its impacts on river basins and floodplains (Darby et al., 2016) will need to be considered carefully. The Mekong river system supports the world's largest inland fishery, constitutes the main source of animal protein in the region, and is fundamental to food security, especially in the Lower Mekong Basin. Finally, due to the elongation of supply chain partly driven by urbanisation the impacts on rising food waste volumes will also need to be considered in legislation.

Mekong governments also need to design holistic food systems policies to help make different types of healthy foods available, affordable and nutritious and it can restrict the advertising of unhealthy foods and introduce nutrition labelling on high caloric foods. In addition, taxing unhealthy products coupled with healthy public lifestyle campaigns are other approaches.

\section{Future research suggestions}

This paper has applied a food systems analytical perspective to explore the drivers and implications of agrarian and food transitions in the Mekong region with a particular focus on smallscale farmers. We now build on this interdisciplinary review by proposing a set of four areas and associated research questions focused on the key transitions that offer opportunities for interdisciplinary research. This paper also shows the value of bringing together concepts of food systems, agrarian change, political economy and sustainable livelihoods to unpack the complexities of global patterns of food production, distribution and consumption, and how these shape what have historically been agricultural livelihoods.
Our first set of research questions addresses the patterns of change of rural livelihoods. While this is an area of research that has an established history that has drawn on and contributed to theories of agrarian change, there is added value to incorporating concepts of food systems. That livelihood strategies of small-scale farmers are going through dramatic change, and that farmers are caught in new structures and patterns of production and trade is not necessarily new. However, the implications of these changes are more complex and multi-faceted, with less clear trajectories of future change. These questions include the following: What are the main trends, changes and trajectories in the Mekong food system that have implications for wellbeing and food security of small-scale farmers? What survival mechanisms have households used in response to changing food production dynamics? How and with what institutional support can these mechanisms be scaled-up to enable rural households to improve their food security, economic and social wellbeing? What have been the impacts of contract farming of food and non-food crops on the livelihoods of small-scale farmers?

Our second set of questions address issues related to dietary transition. From the perspective of small-scale farmers no longer exclusively engaged in subsistence agriculture, we see significant shifts in what is consumed and how it is accessed, while from the perspective of the non-rural consumers we see significant shifts in consumptions patterns. Key questions include: What are the drivers of malnutrition, including overweight/obesity, in the different geographical areas and the Mekong population subgroups? What are the drivers of dietary transitions in rural, urban and semi-urban areas in the Mekong? We need to investigate the impact of the transitions particularly regarding infrastructure on fish stock productivity and other ecosystem services in the Mekong region. How can consumers be supported to improve their food choices and utilization?

Third, we focus on the organisation of supply chains. Gereffi (1994) efined governance as the 'authority and power relationships that determine how financial, material and human resources are allocated and flow within a chain'. It is clear that food system transitions have impacted significantly on the governance of value chains. First, researchers need to unpack the various value chains of food and non-food crops to show the dynamics power and governance in these value chains to assess the opportunity for more equitable inclusive approaches. Our research questions include: What does the existing structure of food supply chains in the Mekong region tell us about their ability to sustain regional livelihoods and food security? What methods and tools can be developed to support more sustainable food chain transformations in the Mekong? What new approaches to managing value chains can result in more holistic and sustainable outcomes across the food system?

Fourth with regard to governance \& regulation our research questions include: What are the key institutions, mechanisms and processes of regional decision-making in the Mekong? How do these regional institutions and processes perform with respect 
to the effectiveness, coherence and participatory aspects of Mekong food system governance? How can these institutions and processes be made more effective, coherent and participatory, and responsive to the needs of rural communities?

Significantly, there is a final set of questions that underpin the food systems approach that focuses on the environmental dimensions of food across the cycle of production, storage, distribution, retail and consumption. The study of environmental dimensions of food has tended to focus on the impacts at particular points within food systems. The emerging challenge is to pull these different environmental aspects together to assess the ways in which they are inter-related and inter-connected, and that environmental impacts at one point in the food system might generate cascading impacts across multiple scales. The major research challenge for environmental considerations is therefore to accommodate the global and household scale, and the linkages between and across them.

\section{Data availability}

No data are associated with this article.

\section{Grant information}

This research is part of the N8 Agrifood programme funded by the Higher Education Funding Council for England.

The funders had no role in study design, data collection and analysis, decision to publish, or preparation of the manuscript.
ADB: Climate Change and Rural Communities in the Greater Mekong Subregion. A Framework for Assessing Vulnerability and Adaptation Options. ADB: Bangkok. 2014.

Reference Source

ADB: Strategy for Promoting Safe and Environment-Friendly Agro-Based Value Chains in the Greater Mekong Subregion and Siem Reap Action Plan. 2017. Reference Source

ADB: Risk Financing for Rural Climate Resilience in the Greater Mekong Subregion. Greater Mekong Subregion Core Environment Program. ADB:

Mandaluyong City. 2017a.

Reference Source

Anderson Irrigation: Increasing the Efficiency and Effectiveness of Pumped Irrigation Schemes in the Central Dry Zone of Myanmar. Working Paper No. 3 - Agriculture. Yangon: Livelihoods and Food Security Trust Fund /UNOPS. Water Resources Utilization Department. 2012.

Reference Source

Araghi F: Food regimes and the production of value: some methodological issues. J Peasant Stud. 2003; 30(2): 41-70.

Publisher Full Text

ASEAN Economic Community Blueprint 2025. Jakarta: ASEAN Secretariat 2015.

Reference Source

Bangkok Post: Relief for Rubber Farmers after price slump. 20th November, 2018.

Reference Source

Bello W, Cunningham S, Poh LK: A Siamese tragedy: Development and Disintegration in Modern Thailand. London and New York: ZED Books. 1998. Reference Source

Béné C, Friend RM: Poverty in small-scale fisheries: old issue, new analysis. Prog Dev Stud. 2011; 11(2): 119-144.

Publisher Full Text

Bernstein H: Land reform: Taking a long(er) view. Journal of Agrarian Change. 2002; 2(4): 433-463.

Biba S: China's continuous dam-building on the Mekong River. J Contemp Asia. 2012; 42(4): 603-628.

Publisher Full Text

Blair G, Blair N: Nutrient Status of Cambodian Soils, Rationalisation of Fertiliser Recommendations and the Challenges ahead for Cambodian Soil Science. Current Agricultural Research Journal. 2014; 2(1): 5-13.

Publisher Full Text

Bowlen B, Bucher J, Bush E, et al.: Income Inequality within Southeast Asia. London, Foresight. 2012

Briones R, Felipe J: Agriculture and structural transformation in developing Asia: review and outlook. Asian Development Bank Economics Working Paper Series, (363). 2013

Reference Source

Bullard N, Bello W, Malhotra K: Taming the tigers: the IMF and the Asian crisis. Third World Q. 1998; 19(3): 505-556.

Publisher Full Text

Cash D, Adger WN, Berkes F, et al:: Scale and cross-scale dynamics: governance and information in a multilevel world. Ecol Soc. 2006; 11(2): 8. Publisher Full Tex
Chainuvati C, Athipanan W: Crop diversification in Thailand. Bangkok, FAO Regional office for Asia and the Pacific. 2001; 130-146.

Reference Source

Conway G: On being a smallholder. In Conference on new directions for smallholder agriculture. 2011; 24-25.

Coxhead I (ed): Routledge Handbook of Southeast Asian Economics.

Routledge; London and New York. 2015.

Reference Source

Cramb RA, Gray GD, Gummert M, et al.: Trajectories of Rice-Based Farming

Systems in Mainland Southeast Asia. Australian Centre for International

Agricultural Research. 2015

Reference Source

Dao N: Rubber plantations in the Northwest: rethinking the concept of land grabs in Vietnam. J Peasant Stud. 2015; 42(2): 347-69.

Publisher Full Text

Darby SE, Hackney CR, Leyland J, et al.: Fluvial sediment supply to a megadelta reduced by shifting tropical-cyclone activity. Nature. 2016; 539(7628): 276-279.

PubMed Abstract | Publisher Full Text

Davis M: Planet of slums: urban involution and the informal proletarian. New Left Review. 2004; 26: 5-34.

Reference Source

De Koninck R, Ahmat R: A state-orchestrated agrarian transition on the Kedah Plain of Peninsular Malaysia, 1972-2009. In: Rigg J \& Vandergeest P (Eds.), Revisiting rural places: Pathways to poverty and prosperity in Southeast Asia. Singapore, Honolulu: NUS Press, Hawaii University Press. 2012; 52-67.

Deininger K, Beyerlee D: The Rise of Large Farms in Land Abundant Countries: Do They Have a Future? World Dev. 2012; 40(4): 701-714.

Publisher Full Text

Delang CO: Deforestation in northern Thailand: The result of Hmong farming practices or Thai development strategies? Soc Nat Resour. 2002; 15(6): 483-501. Publisher Full Text

Doherty B, Ensor J, Heron T, et al: Food Systems Resilience: Towards an Interdisciplinary Research Agenda [version 1; peer review: 3 approved]. Emerald Open Res. Sustainable Food Systems. 2019; 1: 4.

Publisher Full Text

Diepart JC: THEY WILL NEED LAND! -The current land tenure situation and future land allocation needs of smallholder farmers in Cambodia. MRLG

(Mekong Region Land Governance). 2016.

Reference Source

Eaton C, Shepherd A: Contract farming: partnerships for growth. FAO Agricultural Services Bulletin No 145. Rome: Food and Agricultural Organisation. 2001.

Reference Source

Ericksen PJ: Conceptualizing food systems for global environmental change research. Glob Environ Change. 2008; 18(1): 234-245.

Publisher Full Text

Fairhead J, Leach M, Scoones I: Green grabbing: a new appropriation of nature? J Peasant Stud. 2012; 39(2): 237-61.

Publisher Full Text

FAO: Keeping the land alive [WWW document]. 1993; (accessed 4 December 2017).

Reference Source 
FAO: Improving Plant Nutrient Management for better Farmer Livelihoods, Food Security and Environmental Sustainability. Proceedings of a Regional Workshop, Beijing, China, 12-16 December 2005 [WWW document]. 2006; (accessed 6 December 2017).

Reference Source

FAO: The State of the World's Land and Water Resources for Food and Agriculture. Managing Systems at Risk. Earthscan \& FAO: Abington. 2011. Reference Source

FAO: Smallholders and family farmers. Sustainability pathways, factsheet. 2012 Reference Source

FAO: State of the World's Forests. Forests and Agriculture: Land-use challenges and opportunities. Rome: FAO. 2016.

Reference Source

Food and Agriculture Organization (FAO): Impacts of climate change on fisheries and aquaculture- synthesis of current knowledge, adaptation and mitigation

options. Rome. 2018.

Reference Source

Fox J, Castella JC: Expansion of rubber (Hevea brasiliensis) in Mainland Southeast Asia: what are the prospects for smallholders? J Peasant Stud. 2013; 40(1): 155-170.

Publisher Full Text

Friend R: Whose 'nature' counts in natural resource management?: a study of a wetland fishery in southern Thailand. (Doctoral dissertation, University of Bath). 1997.

Reference Source

Friend R: Securing sustainable livelihoods through wetland management: reflections on experience under the Mekong Wetlands Biodiversity \& Sustainable Use Programme (MWBP). Technical Report IUCN/MWBP, Vientiane: Lao PDR. 2007.

Reference Source

Friend $R$, Thinphanga $P$ : Urban water crises under future uncertainties: the case of institutional and infrastructure complexity in Khon Kaen, Thailand. Sustainability. 2018; 10(11): 3921.

Publisher Full Text

Friedmann H: Distance and Durability: Shaky Foundations of the World Food Economy. Third World Q. 1992; 13(2): 371-83.

Publisher Full Text

Friedmann H, McMichael P: Agriculture and the state system: The rise and decline of national agricultures, 1870 to the present. Sociol Ruralis. 1989; 29(2): 93-117.

Publisher Full Text

Fu Y, Chen J, Guo H, et al.: The role of non-timber forest products during agroecosystem shift in Xishuangbanna, southwestern China. For Policy Econ. 2009; 11: 18-25.

Publisher Full Tex

$\mathrm{Fu}$ Y, Chen J, Guo H, et al:: Agrobiodiversity loss and livelihood vulnerability as a consequence of converting from subsistence farming systems to commercial plantation-dominated systems in Xishuangbanna, Yunnan, China a household level analysis. Land Degrad Dev. 2010; 21(3): 274-284.

Publisher Full Text

Gereffi G: The organization of buyer-driven global commodity chains: how US retailers shape overseas production networks. Contributions in economics and economic history. 1994; 95-122.

Reference Source

Goodman D, Redclift M: Refashioning nature: food, ecology and culture. Routledge. 2002.

Publisher Full Tex

Gomez Ml, Garrett CB, Raney T, et al: Post-green revolution food systems and the triple burden of malnutrition. Food Policy. 2013; 42: 129-138.

Publisher Full Text

Gorman T, Beban A: Of migrants and middlemen: Cultivating access and challenging exclusion along the Vietnam-Cambodia border. Asia Pac Viewp. 2016; 57(2): 207-20

Publisher Full Text

Gregory PJ, Ingram JSI, Brklacich M: Climate change and food security. Philos Trans R Soc Lond B Biol Sci. 2005; 360(1463): 2139-2148.

PubMed Abstract | Publisher Full Text | Free Full Text

Haddad L, Cameron L, Barnett I: The double burden of malnutrition in SE Asia and the Pacific: priorities, policies and politics. Health Policy Plan. 2015; 30(9): 1193-1206.

PubMed Abstract | Publisher Full Text

Hart AK, McMichael P, Milder JC, et al:: Multi-functional landscapes from the grassroots? The role of rural producer movements. Agric Hum Values. 2016; 33(2): 305-322.

Publisher Full Text

Hirsch P, Scurrah N: The Political Economy of Land Governance in Lao PDR. Mekong Region Land Governance (MRLG), Vientiane. 2015a

Reference Source

Hirsch P, Scurrah N: The Political Economy of Land Governance in the Mekong Region. Mekong Region Land Governance (MRLG), Vientaine, Lao PDR. 2015b. Reference Source

Horton P, Banwart SA, Brockington D, et al.: An agenda for integrated systemwide interdisciplinary agri-food research. Food Security. 2017; 9(2): 195-210.

Publisher Full Text
IFAD (International Fund for Agricultural Development): Smallholders Can Feed the World. Rome: IFAD. 2012.

Reference Source

Ingram J: A food systems approach to researching food security and its interactions with global environmental change. Food Secur. 2011; 3(4): 417-431. Publisher Full Text

Johnston R, Hoanh Chu T, Lacombe G, et al.: Scoping Study on Natural Resources and Climate Change in Southeast Asia with a Focus on Agriculture. Report prepared for the Swedish International Development Cooperation Agency by International Water Management Institute, Southeast Asia (IWMI-SEA). Vientiane, Laos: International Water Management Institute, South East Asia. 2009.

Reference Source

Kneen B: From Land to Mouth. Toronto: NC Press. 1993.

Reference Source

Laurujisawat P: CPF: a case study of the best Practice Contract Farming drives

Thai, AEC and World Agricultural development. 2012.

Reference Source

Lu XX, Siew RY: Water discharge and sediment flux changes over the past decades in the Lower Mekong River: possible Impacts of the Chinese dams.

Hydrol Earth Syst Sci. 2006; 10(2): 181-195.

Publisher Full Text

Manorom K, Hall D, Lu X, et al:: Cross-border contract farming arrangement: Variations and implications in the Lao people's democratic Republic. Asian Development Bank. 2011.

Reference Source

McElwee G: Farmers as entrepreneurs: developing competitive skills. J Dev

Entrep. 2006; 11(03): 187-206.

Publisher Full Text

McMichael P: Global development and the corporate food regime. In New directions in the sociology of global development. Edited by: Buttel, F. H. and McMichael, P., Oxford: Elsevier Press. 2005

Publisher Full Text

McMichael P: Contemporary contradictions of the global development project: geopolitics, global ecology and the 'development climate'. Third World Q. 2009; 30(1): 247-62.

Publisher Full Text

Molle F, Srijantr T: Agrarian change and land system in the Chao Phraya Delta.

DORAS-DELTA Research Report No. 6. Bangkok: Kasetsart University. 1999

Publisher Full Text

MSU/MDRI/CESD: A Strategic Agricultural Sector and Food Security Diagnostic for Myanmar. USAID, Burma: Yangon. 2013.

Reference Source

Nolte C, Gobbi B, de Waroux YLP, et al:: Decentralized land use zoning reduces large-scale deforestation in a major agricultural frontier. Ecol Econ. 2017; 136: $30-40$.

Publisher Full Text

Parsons L, Lawreniuk S, Pilgrim J: Wheels within wheels: poverty, power and patronage in the Cambodian migration system. J Dev Stud. 2014; 50(10): 1362-1379.

Publisher Full Text

Patel R: Stuffed and starved. Markets, power and the hidden battle over the world's food system. London: Portobello Books. 2007.

Permani R, Vanzetti D: Rice mountain: assessment of the Thai rice pledging program. Agric Econ. 2016; 47(3): 273-284.

Publisher Full Text

Phongpaichit P, Baker C: Thailand's boom and bust. Chiang Mai: Silkworm Books. 1998; 105.

Reference Source

Pinstrup-Andersen P, Watson DD: Food Policy for Developing Countries. Ithaca, NY: Cornell University Press. 2011.

Reference Source

Purotaganon M, Schmidt-Vogt D: Agricultural intensification in the Bang Phluang Irrigation Scheme, Prachinburi Sub-basin, Thailand, and its impacts on water management. Int J Water Resour Dev. 2014; 30(2): 308-321.

Publisher Full Text

Reardon T, Timmer CP: The economics of the food system revolution. Annu Rev Resour Economics. 2012; 4: 225-264.

Publisher Full Text

Reardon T, Echeverria R, Berdegue J, et al:: Rapid transformation of food systems in developing regions: highlighting the role of agricultural research \& innovations. Agricultural Systems. 2019; 172: 47-59.

Publisher Full Text

Rigg J: Land, farming, livelihoods, and poverty: rethinking the links in the rural south. World Dev. 2006; 34(1): 180-202

Publisher Full Text

Rigg J, Nattapoolwat S: Embracing the global in Thailand: activism and pragmatism in an era of deagrarianization. World Dev. 2001; 29(6): 945-960. Publisher Full Text

Rigg J, Salamanca A: The devil in the detail: interpreting livelihood turbulence from a 25-year panel study from Thailand. Area. 2015; 47(3): 296-304. Publisher Full

Rigg J, Salamanca A: Aggregate trends, particular stories: tracking and explaining evolving rural livelihoods in Southeast Asia. Routledge Handbook 
of Southeast Asian Development, A. McGregor, L. Law, and F. Miller (eds.). Routledge, London 2018; 39-52.

Reference Source

Rigg J, Salamanca A, Parnwell M: Joining the dots of agrarian change in Asia: A 25 year view from Thailand. World Dev. 2012; 40(7): 1469-1481.

Publisher Full Text

Rigg J, Salamanca A, Phongsiri M, et al.: More farmers, less farming?

Understanding the truncated agrarian transition in Thailand. World Dev. 2018; 107: $327-337$.

Publisher Full Text

Rigg J, Salamanca A, Thompson EC: The puzzle of East and Southeast Asia's persistent smallholder. J Rural Stud. 2016; 43: 118-33.

Publisher Full Text

Rotz S, Fraser ED: Resilience and the industrial food system: Analyzing the impacts of agricultural industrialization on food system vulnerability. Journal of Environmental Studies and Sciences. 2015; 5(3): 459-473.

Publisher Full Text

Sangkumchaliang P, Huang WC: Consumers' perceptions and attitudes of organic food products in Northern Thailand. International Food and Agribusiness Management Review. 2012; 15(1): (1030-2016-82915).

Reference Source

SCB: Thailand's drought crisis 2016: Understanding it without the panic. Note by EIC Analysis. [WWW document]. 2016; (accessed 28 November 2017). Reference Source

Schoenberger L, Hall D, Vandergeest $P$ : What happened when the land grab came to Southeast Asia? J Peasant Stud. 2017; 44(4): 697-725.

Publisher Full Text

Seck PA, Diagne A, Mohanty S, et al.: Crops that feed the world 7: Rice. Food Secur. 2012; 4(1): 7-24.

Publisher Full Text

Shove E, Walker G: Governing transitions in the sustainability of everyday life. Res Policy. 2010; 39(4): 471-476.

Publisher Full Text

Sobal J, Khan LK, Bisogni C: A conceptual model of the food and nutrition system. Soc Sci Med. 1998; 47(7): 853-863.

PubMed Abstract | Publisher Full Text

Sreymom S, Pirom K: Contract farming in Cambodia: different models, policy and practice. CDRI Working Paper Series 104.2015.

Reference Source

Sriboonchitta S, Wiboonpoongse A: Overview of contract farming in Thailand: lessons learned. ADBI Discussion Paper 112. Tokyo: Asian Development Bank Institute. 2008

Reference Source

Tendall DM, Joerin J, Kopainsky B, et al.: Food system resilience: defining the concept. Global Food Secur. 2015; 6: 17-23.

Publisher Full Text

Thapa GB, Viswanathan PK, Routray JK, et al: Understanding the next agricultural transition in Asia: a critical review of major facets and future challenges. Millenial Asia. 2010; 1(2): 215-239.

Publisher Full Text

Tubtim T: Migration to the countryside. Crit Asian Stud. 2012; 44(1): 113-130. Publisher Full Text

UNDP: Building Resilience: the future of rural livelihoods in the face of climate change. The Cambodia UN Human Development Report 2011, UNDP: Cambodia. 2011.

Reference Source

Waddington SR, Li X, Dixon J, et al:: Getting the focus right: production constraints for six major food crops in Asian and African farming systems.

Food Secur. 2010; 2(1): 27-48.

Publisher Full Text

Wahlqvist ML, McKay J, Chang Y, et al:: Rethinking the food security debate in Asia: some missing ecological and health dimensions and solutions. Food Secur. 2012; 4(4): 657-670.

Publisher Full Text

Walker A: Agricultural Transformation and the Politics of Hydrology in Northern Thailand. Dev Change. 2003; 34(5): 941-964.

Publisher Full Text

WFP (World Food Programme): Response Strategy for Food Insecurity in Zimbabwe 2012/13. WFP Rome 2012.

Reference Source

Winichagoon P: Thailand nutrition in transition: situation and challenges of maternal and child nutrition. Asia Pac J Clin Nutr. 2013; 22(1): 6-15.

PubMed Abstract | Publisher Full Text

Winkels A: Stretched livelihoods - The social and economic connections between the Red River Delta and the central highlands. In Sikor T, Nghiem PT, Sowerwine J, \& Romm J, (Eds.), Upland transformations: Opening boundaries in Vietnam. Singapore: National University of Singapore Press. 2011.

Reference Source

Wittayapak C: Who are the farmers? Livelihood trajectories in a Northern Tha Village. In Rigg J, \& Vandergeest P, (Eds.), Revisiting rural places: Pathways to poverty and prosperity in Southeast Asia. Singapore, Honolulu: NUS Press, Hawail University Press. 2012; 211-228.

Xu J, Ma ET, Tashi D, et al.: Integrating sacred knowledge for conservation: cultures and landscapes in southwest China. Ecol Soc. 2005; 10(2): 7.

Reference Source

Yasmi Y, Durst P, UI Haq R, et al.: Forest change in the Greater Mekong Subregion (GMS): An overview of negative and positive drivers. Bangkok: FAO. 2017.

Reference Source 


\section{Open Peer Review}

\section{Current Peer Review Status:}

\section{Version 1}

Reviewer Report 12 July 2019

https://doi.org/10.21956/emeraldopenres.14171.r26400

(C) 2019 Ross H. This is an open access peer review report distributed under the terms of the Creative Commons Attribution License, which permits unrestricted use, distribution, and reproduction in any medium, provided the original work is properly cited.

\section{Helen Ross}

School of Agriculture and Food Sciences, University of Queensland, Brisbane, QId, Australia

This is a very well crafted article, that makes an important intellectual (and practical) contribution to the growing area of food systems. Its main contribution is to highlight actors, not to my knowledge noted in the existing literature on food systems.

The review overall is very rich, and makes interesting reading.

As the authors note, the existing literature on food systems tends to be internationally generic. It is thus pleasing to see smallholder farmers highlighted here. I was also pleased to see the inclusion of fisheries, often left out of food analyses. Similarly, it is good to see recognition of supply chains.

I felt the excellent review about issues in complexity is not yet delivering on the key argument of need to augment a food systems analysis with focus on actors, knowledge, and power. There are hints, but not the weight of evidence to sustain the argument put. I thus recommend that this aspect of the case study be developed to fully sustain the argument.

Is the topic of the opinion article discussed accurately in the context of the current literature?

Yes

Are all factual statements correct and adequately supported by citations? Yes

Are arguments sufficiently supported by evidence from the published literature? Partly

Are the conclusions drawn balanced and justified on the basis of the presented arguments? Yes 
Is the argument information presented in such a way that it can be understood by a nonacademic audience?

Yes

Does the piece present solutions to actual real world challenges?

Yes

Is real-world evidence provided to support any conclusions made?

Yes

Could any solutions being offered be effectively implemented in practice?

Yes

Competing Interests: No competing interests were disclosed.

Reviewer Expertise: social sciences in social-ecological systems

I confirm that I have read this submission and believe that I have an appropriate level of expertise to confirm that it is of an acceptable scientific standard.

Reviewer Report 18 June 2019

https://doi.org/10.21956/emeraldopenres.14171.r26386

(c) 2019 Crang M. This is an open access peer review report distributed under the terms of the Creative Commons Attribution License, which permits unrestricted use, distribution, and reproduction in any medium, provided the original work is properly cited.

\section{Michael Crang}

Durham University, Durham, United Kingdom

The paper marshals a fascinating array of detail to suggest a complex picture in the Mekong that aligns with its plea for holistic analysis. It can end up being hard to follow then as it moves between data in different countries and scales fort different elements of food production. The repeated claim and evidence of the continued presence of small-scale producers which is really significant thus seems to contradict the food regime history (which is presented as a grand sweep largely unlocated in period or place). There are then moments when it presents evidence of growing and persisting small scale producers and within a page claims of their demise. Partly that reflects the reflexivity of policy, which is enacting predictions of their demise (as the paper evidences but does not quite put in those terms, where it sees feedback loops in environmental consequences rather than a performative understanding of the constitution of the economy, and indeed the food system), partly mixed evidence from different countries and most significantly the paper shows changing senses of what small scale producers actually are. There is lovely detail on the farmers who fish and fishers who farm, and some perhaps underplayed references to remittances from family members in non-agricultural work. 
Conceptually, the paper offers a strong critique of the way agrifood systems theory tends to first evacuate politics, culture and 'other' social systems and, second, that the typical closure of a system is at a national scale. The paper sets out to complexify the systems involved focusing on the Mekong as a significant agri-food system. It faces the problem it describes of then delimiting that system spatially and sectorally. It is largely correct in its diagnosis of a focus of agri-food system work on the 'agri' end of that system and as it concludes there is a need for more work 'that focuses on the environmental dimensions of food across the cycle of production, storage, distribution, retail and consumption.' As a review it inevitably replicates the pattern with very little discussion of storage, or distribution aside from some export data, a small part looking mostly at one company in Thailand addressing retail (and one line on p11) and some indicators of obesity and diet being the only elements of the range of economies and practices of consumption. So to take a case when it refers to infrastructures it moves to dams and irrigation (which is indubitably very important) but not to say roads for shipping produce to markets, to refrigeration units for enabling that produce to perdure during transit, or domestic refrigeration (or the lack thereof) influencing its patterns of consumption.

Some untidy moments need ironing out. There are numerous moments when it is unclear how things follow each other analytically - at a trivial level we have a 'triple burden' of malnutrition in one paragraph followed by a 'double burden' in the next (p.11), or one paragraph is addressing Thailand the next the whole region (eg. on contract farming) which again makes the argument difficult and the piece rather bitty. Obviously a chunk of this is driven by the patchiness of data and its lack of reliability -- which is a point well made. But it is added to by some slips in writing such as land areas given in non-SI units making assessment difficult, the inland fishery is given in 'fish per year' where it probably means tonnes of fish per year not a count of individual animals (which would tally then with the consumption per head by $\mathrm{kg}$ ), we are told the official statistic underplay both rural and urban populations ('Official statistics have consistently underestimated and misrepresented residence in the urban or rural ' p6) which means the argument of overlooking rural production is harder to sustain, and bullet points like 'The cultural stickiness of land; "if there is no land where can I stand"' are left as self-explanatory devoid of source or interpretation. The inevitable bitterness of multiple country exemplar data is compounded by some slackness then in writing when table one introduces Charoen (NB spelling different to later) Pokphand Foods several pages before we get told what or where it is, or the sentence explain things like expanding commercial tea production as 'Non-food production includes commodities such as tea, coffee, and animal feed, and due to their low nutritional values are not consumed' - I had never thought tea was primarily assessed for nutritional value. Overall, we get a compelling but sometimes bewildering range of indicators from different countries.

What that all shows us is that above all there is no simple uniform pattern - across the Mekong let alone globally. It gives us a powerful sense that changes at one point have consequences at others. What it does not then say is which changes are driving others nor how non-environmental feedback loops work. It raises the question of how difficult it is to delimit system boundaries and sub-system boundaries, which at a more profound level might make one ask whether 'systems' theory is a good model - or maybe non-linear systems, or Luhmann's or Maturana and Varela's autopoetic models of systems feedback might be interesting conceptual avenues.

\section{Is the topic of the opinion article discussed accurately in the context of the current literature?}


Yes

Are all factual statements correct and adequately supported by citations?

Partly

Are arguments sufficiently supported by evidence from the published literature?

Yes

Are the conclusions drawn balanced and justified on the basis of the presented arguments?

Yes

Is the argument information presented in such a way that it can be understood by a nonacademic audience?

Yes

Does the piece present solutions to actual real world challenges?

Yes

Is real-world evidence provided to support any conclusions made?

Yes

Could any solutions being offered be effectively implemented in practice?

Yes

Competing Interests: No competing interests were disclosed.

I confirm that I have read this submission and believe that I have an appropriate level of expertise to confirm that it is of an acceptable scientific standard. 